\title{
Insularity and Ambivalence: The Case of the South African Poet P. J. Philander's Epic Poem, Zimbabwe
}

\author{
HEIN WILLEMSE \\ University of Pretoria, South Africa
}

\begin{abstract}
This essay explores the South African author P. J. Philander's epic Zimbabwe (1968), an Afrikaans poem of 307 alternate quatrains largely based on the disproved notion that the Phoenicians built the ancient complex of Great Zimbabwe and established a religion of phallic or fertility worship. The essay initially traces the longstanding debate on the "mystery" of Great Zimbabwe and arrives at the conclusion that the poet made a deliberate choice for the Semitic or Phoenician thesis. In the second phase of the discussion, Zimbabwe is read with Frantz Fanon's classic text Les damnés de la terre, especially with regard to the complex but key binary relationship between settlers and aboriginals. In conclusion, the essay discusses the author's political ambivalence and his attempts at making the rise and decline of Great Zimbabwe applicable to apartheid South Africa.
\end{abstract}

\footnotetext{
outh African education policies, under successive apartheid regimes, actively discouraged knowledge or identification with countries to the north of the Limpopo River. The wide insularity that was subsequently brought about meant that for most South Africans, "Africa" was a world apart: unknown and feared. Where South African authors do explore Africa beyond the confines of their country the results are intriguing. This essay explores the South African author P. J. Philander's epic, Zimbabwe (1968), an Afrikaans poem of 307 alternate quatrains largely based on the disproved notion that the Phoenicians built the ancient complex of Great Zimbabwe and established a religion of phallic or fertility worship. The essay initially traces the longstanding debate on the "mystery" of Great Zimbabwe and arrives at the conclusion that the poet made a deliberate choice for the Semitic or Phoenician thesis. In the second phase of the discussion, Zimbabwe is read with Frantz Fanon's classic text Les damnés de la terre, especially
} 
with regard to the complex but key binary relationship between settlers and aboriginals. In conclusion, the essay discusses the author's political ambivalence and his attempts at making the rise and decline of Great Zimbabwe applicable to apartheid South Africa.

P. J. Philander (1921-2006) grew up in an undulating, sheep farming, and fertile grainproducing region of South Africa, the Overberg in the South Western Cape. He completed his primary school studies in a rural town, Caledon, and qualified as a primary school teacher at a teachers' training school in the city of Cape Town. As a young teacher he taught in several small towns, while he embarked on part-time matriculation and university study. He later completed a Bachelor of Arts degree through the University of South Africa, a correspondence university. By 1955, at the time of his debut collection of poetry, he was the first headmaster of a newly established high school in the rural town of Malmesbury. In 1957, he accepted a similar position in Cape Town. He visited Europe and the United States of America in 1961. By 1968, two of his three sons had commenced graduate studies in the USA. In 1969, he and his family immigrated to the USA, where he continued teaching in the New York City school system. Philander, who wrote in Afrikaans, produced seven collections of poetry, one novel, a collection of short stories, a collaborative project with a visual artist and two selections from his published poetry (see Works Cited). Philander with his friend and fellow Afrikaans poet S. V. Petersen also published several social science textbooks prescribed exclusively in the primary schools of the Department of Coloured Affairs, a government department established under the apartheid policies of the National Party to serve the needs of the "Coloured population group." By the time of his immigration, Philander was a well-known and established figure in coloured educational and Afrikaans literary circles.

Prior to his departure he had published three collections of poetry: Uurglas (Hourglass, 1955), Vuurklip (Firestone, 1960) and Zimbabwe (1968). In 1961, his second collection received "the runners-up and only award" in a literary competition organized by the South African Department of Education, Art and Science (see Die Burger 31.03.1960). In 1963 he received a medal of honor for his services to Afrikaans Literature from the whites-only Suid-Afrikaanse Akademie vir Wetenskap en Kuns (South African Academy of Science and Art). With these two awards Philander achieved rare recognition - a black man recognized for his literary achievements by exclusivist, pro-apartheid, Afrikaner establishment organizations. ${ }^{1}$

Philander is one of the first writers classified "coloured" (kleurling in Afrikaans) under apartheid legislation to publish in the establishment Afrikaans literary system-a sociopolitical fact that always seems to accompany his literary biography: "Ek voel myself net digter, maar is ek 'n Kleurlingdigter" 'I feel myself just a poet, but I am [perceived as] a Coloured poet' (qtd. in Rautenbach en Retief 21). ${ }^{2}$ The social and political position of the coloured-"mixed raced"-subject in South African politics is often perceived as marginal, occupying an intermediate space between the "black majority" and the "white minority" At the beginning of the 1980s, an Afrikaner literary critic introduced him as follows: "P. J. Philander het saam met Adam Small in die vyftiger-, sestigerjare die stem van die Bruinmens in ons poësie geword" 'P. J. Philander along with Adam Small in the fifties, sixties became the voice of the Bruinmens [a polite equivalent for coloured often considered less offensive in Afrikaans speaking circles-HW] in our poetry' (Cloete 
147). Another earlier critic characterized some of the literary tendencies in the midtwentieth century as "En dan is daardie wrange klag, die satire en opstandigheid van die Kleurling" 'the wry accusation, the satire and the rebelliousness of the Coloured [Petersen, Philander, Small]' (Dekker 179). A contemporary literary critic regards Philander, this time without the adjectival qualification "coloured," as "'n onmisbare stem" 'an indispensable voice' since the publication of his first collection of poetry in 1955 (Hugo 407). ${ }^{3}$

Afrikaans literary critics received Philander's first two collections well. In general they contended that his collections showed poetical complexity and depth and employed a creative use of language, and they admired the poet's exploration of little known historical topics and themes. Of his first three collections, Zimbabwe, an epic poem on a supposed ancient civilization of Great Zimbabwe, received the least favorable criticism, with at most a handful of superficial reviews, no longer than a page or two, most much shorter. The critics disapproved of Philander's alleged reliance on contemporary Afrikaans poets or literary antecedents - in plot and versification-or its "barok oordaad en beskrywingswellus" 'baroque excess and wanton descriptions' (Kannemeyer 215; see also Lindenberg 71). Overall the epic is regarded as "lomp, met rymdwang" 'awkward, with rhyming compulsion' (Cloete 147); "'n prysenswaardige poging, maar as 'n geheel slaag die werk nie" 'a commendable effort, but as a whole the work does not succeed' (Kok 91) or as a "prekerigheid en dorre relaas" 'preachy and dull account' (Kannemeyer 215). In short: this severe criticism meant that Zimbabwe, Philander's most ambitious work, has not been explored to any significant degree.

The epic has eight divisions. The first division, "Sonnewende" (solstice), from quatrains 1 to 59, is the longest and tells of the arrival "op die branding" 'on the surf (9) of the "lang swart [haar]" 'long black-haired' (12) people from a distant dry territory in a lusciously wooded land. These new arrivals — named the "Zimbabwe people"— go to great lengths to keep themselves apart from their immediate "oerwoudbure" 'jungle neighbors' (13) and other "kinders van die net" 'children of the reed' (15). They build a temple and citadel of stone, shun the approaches of the "opperhoof van die kraal" 'chief of the kraal' (15), and prohibit any contact between their maidens and the aboriginal inhabitants. From their relatively advanced civilization the Zimbabwe people bring new technologies such as the smelting of gold or the manufacturing of jewelry. They also indulge in phallic worship, a vestige of their ancient culture. In comparison, the aboriginals' customs are "beperk tot hout, ivoor, klei" 'limited to wood, ivory, clay' (17), while their shaman dreams and "Afrika bly lomerig, lou ... ." Africa remains languid, tepid .. .' (18).

Divisions two (quatrains 60-85) and three (quatrains 86-120) introduce the main character Ulali and her son Nimra, respectively Ulali recounts her life as a young woman in a culture where eunuchs guard the settlements' maidens and at an appointed time take them through subterranean tunnels to the temple to satisfy, as part of their civilization's phallic or fertility worship, their priests' sexual needs. She recalls that her mother had to endure the same and that as a woman her own prospects would be little different. In the third division, Ulali tells of her enforced visit to the temple and the conception, birth, and early life of her son. She predicts that her only child, whose father she does not know, may be sacrificed to enhance the priests' physical strength. 
The fourth division, entitled "Passaat" (Trade winds—quatrains 121-66), deals with Nimra's disappearance and Ulali's longing and her desperate search through the Zimbabwe complex, along the walls and into the subterranean passageways. Outside the walls there are indications of fires and pending attacks. A menacing horde of "die barbare" 'barbarians' demands "die goud van die smelt-potte [...]/ [en] (hoor) ons merimba's ook binnensmuur / en met julle vrouens onder die sterre lê" 'the gold of the crucible [...]/ [and] (hear) our marimbas inside the walls and / lie down with your women under the stars' (44). The Zimbabwe people do not accede to their demands and they attack the settlement and almost burn it down.

Raset, the hunter and Ulali's partner, is the subject of the fifth division (quatrains 167-201). He is responsible for the settlement's emergency provisions, and according to him "Zimbabwe verloor sy blom" 'Zimbabwe is losing its luster' (54). The settlers fear that the locals will swamp them and that any association will bring about the loss of their culture and eventually their total demise. The first attack causes much damage and, in addition, all sorts of indigenous diseases lay the Zimbabwe men low so that they cannot defend their settlement against the approaching horde. In an attempt at turning their fortunes around, Raset reveals that the priests ordered Ulali's sacrifice, for "na jou dood sal daar weer gloed / diep in ons are skuil" 'after your death sparkle / will again shimmer deep in our veins' (56). As a prelude to her sacrificial death, Ulali in division six, "Antipassaat" (Countertrade winds-quatrains 202-39), is reminded of her son, who apparently died a similar death, and Raset takes her on a journey through the settlement's maze of subterranean passageways.

In the penultimate division, "Klein sikloon" (Little cyclone-quatrains 240-80), Ulali is led to the sacrificial altar, her blindfold is removed, and her long-lost son, Nimra, turns out to be her executioner. ${ }^{4}$ Just as he is about to administer the deathblow, she escapes, Nimra is wounded, and with the help of Raset she escapes from the temple. Having seen Nimra, Ulali realizes that Raset is her son's father. In the eighth, and ultimate division, "Ewenagslyn" (Equator-quatrains 281-307), a storm that "elke wegkruipplek / onder die hemele [ooprits]" 'rips open every hiding place / under the heavens' (83) approaches the settlement while at the same time the "die barbare" or "die bose manne" 'the barbarians' (84), or 'the evil men' (86) outside the walls, prepare for their final attack, still craving for "die trog / van 'n vrou se onderdele" 'the trough / of a woman's lower parts' (85). Just as the settlement is about to be overrun, the women on the instigation of Ulali commit suicide.

Philander's epic continues a tendency in early Afrikaans literary history and South African historiography that assume exotic origination and occupation of Great Zimbabwe. ${ }^{5}$ In order to understand the significance of his choice we need to explore the contested history of Great Zimbabwe and the place of the queen myth, the myth of foreign occupation, also known as the Semitic myth. Before the early twentieth century, most European explorers, writers, colonists, and their representatives imagined the civilization of Great Zimbabwe in essentially Eurocentric terms with the explicit understanding that Africans were incapable of producing such monumental structures, i.e., incapable of having history. Against this background, giving preference to the idea of exotic origination of Great Zimbabwe, as Philander did, is a very ambiguous, if not downright controversial, matter. 
Among Afrikaans speakers the late nineteenth-century politician, educationist, and Dutch Reformed minister S. J. du Toit contributed largely to the creation of the mythology of the "white queen of Zimbabwe." In this regard his influence was arguably greater than that of H. Rider Haggard's King Solomon's Mines (1885) or She (1887). Initially, his historical novel Di Koningin fan Skeba (The Queen of Sheba) circulated as a newspaper serial and was published in 1898 as a novel, with its ninth, abridged reprint in 1963. For years it was a set work prescribed in many South African schools.

In the novel, an unnamed aboriginal character authenticates "history" when he, under duress, relates the secret and privileged story of the white queen. In an attempt at legitimacy, the character calls upon ancestral knowledge to provide irrefutable authority (du Toit, Goudfelde in Sambesia 3; see also du Toit, Skeba 4):

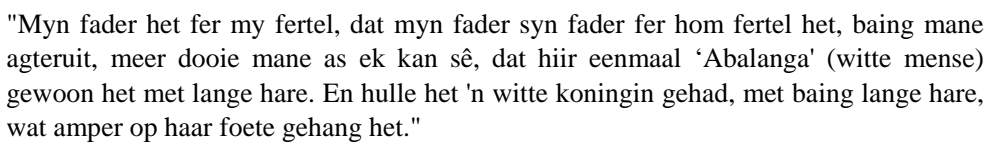

"Myn fader het fer my fertel, dat myn fader syn fader fer hom fertel het, baing mane agteruit, meer dooie mane as ek kan sê, dat hiir eenmaal 'Abalanga' (witte mense) gewoon het met lange hare. En hulle het 'n witte koningin gehad, met baing lange hare, wat amper op haar foete gehang het."

"My father told me, what his father told him, many moons ago, many more dead moons than I can say, that here once 'Abalanga' (white people) with long hair lived. And they had a white queen, with very long hair that almost came to her feet."

In this reported "oral history," the indigenous people are forever under the power of foreigners: "Naderhand is hiir toen weer andere mense gekom fan di grote water af, wat amper nes witte mense is, met lange hare, mar hulle was ni heeltemal wit ni (Arabire en Portugése)" 'Later other people came here, from across the great waters, who are almost like white people, with long hair, but they are not completely white (Arabs and Portuguese).' In the most colonial of constructs, the author does not allow his character to consider the possibility of independent agency by his forebears. No possibility is offered that the indigenous populace may have mined or built Great Zimbabwe; in the words of this character: "Hulle het fer ons gate laat grawe in di grond om 'Isipsi' (goud) uit te haal. Di witte mense het di grote klip krale gebou, so hoog soos di borne ..." 'They [the white people] forced us to make holes in the ground to take out 'Isipsi' (gold). The white people built big stone kraals, as high as the trees ....'

Indicative of the popularity (and general acceptance) of the Semitic myth, or the notion of nonsouthern African influence, is that none of the literary reviewers of Philander's Zimbabwe bothered to explore (or at least comment on) the epic in relation to the long-running controversy on the builders of the Great Zimbabwe complex. They tacitly accepted the contested premise of exotic influence put forward in the poem.

Great Zimbabwe - dating back to between 1200 to 1550 CE-has been the subject of intense conjecture (Garlake 174; see also Pikirayi 3, 129). It is accepted knowledge that at its peak it occupied an important place in the region, either as a religious center or as a powerful political or commercial entity. Over the past century, bitter controversies raged among archaeologists, historians, and lay people; while political activists of all shades waded in to claim it for their particular causes. Early sixteenth-century Portuguese explorers gave hearsay accounts of purported 
mining activities and monumental fortresses of stone without mortar in a region they variously claimed to be the land of the Christian King, Prester John, or the mines of the biblical King Solomon, often linked to the Queen of Sheba (also known as Princess Bilkis) or the empire of Monomatapa (Mwere Mutapa) (see Summers, A Rhodesian Mystery 18; Garlake 51-64).

The German geologist Karl Mauch visited the ruined settlement-consisting of a great enclosure, the valley enclosures and the hill complex-in 1871 and gave some of the first directly observed reports. Biblical history played a major role in his understanding of the ruined buildings; for instance, he regarded the hill complex a replica of King Solomon's temple and the great enclosure as a reproduction of the palace of the Queen of Sheba (see Pikirayi 9-11; 132-40). Mauch departed from the view that "a civilized nation must have lived here"; searching for signs of an ancient civilization, he found a piece of wooden lintel that apparently bore some similarity to Lebanese cedarwood. For him it was a small step to surmise that "only the Phoenicians could have brought it here" or that "the great woman who built the rondeau [the great enclosureHW] could have been none other than the Queen of Seba" (Mauch, qtd. in Garlake 6364). Later, twentieth-century investigations proved that the wood used in the Zimbabwe complex was mopane, a tree indigenous to the region (Summers, Rhodesian Mystery 57).

Mauch's report, but more particularly the work of his successors, J. Theodore Bent and Richard Hall, gave rise to the antiquarian tradition of Zimbabwe culture studies. However, their primary professional orientations often influenced their interpretations. For example, in the case of Bent his training as an orientalist, and in the case of his collaborator, R. M. Swan, his inappropriate astronomical assumptions, led to speculative conclusions. Bent, in some instances ignored obvious indications of indigenous settlement, merely because his findings did not tally with his firm ideas of earlier Phoenician settlement. In these cases he came to seriously flawed conclusions, ignoring the obvious in favor of fancy exposition, for example: "Kaffir remains we found in abundance, and a small cemetery of some twenty graves of rough stone piled over the bodies, about ten miles from Zimbabwe, also Kaffir but nothing else. Consequently we came to the conclusion that the ancient inhabitants, who formed but a garrison in this country, were in the habit of removing their dead to some safer place" (Bent 121).

Bent's explorations resulted in The Ruined Cities of Mashonaland (1892), a travelogue supported by a convoluted comparatist archeological approach that set out to prove that the stone monoliths and conical towers, the so-called phalli, and the general circularity of the Zimbabwe complex had religious significance-since "all the Arabians worshipped a tower"-which apparently pointed to ancient Phoenician temple construction and religious practices, such as sacrifices. ${ }^{6}$ The conical tower, Bent suggested, served as a calendar for the observation of the sun and the stars and that the high walls were fortifications to protect the Semitic traders against "barbaric and hostile tribes." "The occupants were in constant dread of attack," he wrote, "lived like a garrison in the heart of an enemy's country" (Bent 115-24; see also Pikirayi 12-13).

Drawing on Bent and others with similar inclinations, Hall's publications on his rather indiscriminate and scientifically unsophisticated excavations, The Ancient Ruins of Rhodesia (1902, with W. G Neal) and Great Zimbabwe (1905), became well-known and oft-cited authorities. At one point he claimed that he was 
performing "timely preservation work" while he discarded layers of the "the filth and decadence of the Kaffir occupation", with the intention apparently of "revealing the remains of the 'ancient' builders"' (qtd. in Garlake 72). Hall concluded that "ancient Semitic colonizers" built Great Zimbabwe "three millenniums if not four" ago. In a later polemical text, Hall introduced race theories to the effect that "the Bantu" were not a "progressive people" and therefore not capable of monumental architecture (see Garlake 79). His conclusions were disseminated widely; especially when these were taken up in local school history textbooks. Today, archaeologists view his activities as "disastrous", his methods as "lamentable", his evidence as "amorphous" and his conclusions as "subjective impressions" (Garlake 73-75; see also Summers, A Rhodesian Mystery 25-29; Pikirayi 13-14). ${ }^{7}$

Orthodox archaeological methodologies were sorely lacking, and much of the earlier published research was speculative. The work of David Randall-MacIver (Medieval Rhodesia, 1906) and Gertrude Caron-Thompson (The Zimbabwe Culture, 1931) rectified these lacunae. They based their conclusions on painstaking, properly controlled excavations. Randall-MacIver (83) found conclusively that "[i] $\mathrm{n}$ architecture, whether military or domestic, there is not a trace of Oriental or European style of any period whatever [. . .]; [t]hat the character of the dwellings [. . .] is unmistakably African [. . .]; [and] [t]hat the arts and manufactures [. . .] are typically African." Peter Garlake (78) considered Randall-MacIver's approach "fautless," his excavations "careful," and his assessment "unassailable."

A generation later, Caron-Thompson went to great lengths in her excavations, even tunneling directly under the conical tower, the signature structure of the Zimbabwe complex. She confirmed to a large degree the conclusions of Randall-MacIver and refuted key arguments of the antiquarians, for instance, that the gold mining industry was under the control of the Phoenicians. She stated that the conclusion that "the natives of Rhodesia knew nothing of mining at depth, and, therefore, can have had no part in the exploitation of the ancient gold mines, is entirely and utterly fallacious"; furthermore, "examination of all the existing evidence, gathered from every quarter, still can produce not one single item that is not in accordance with the claim of Bantu origin and medieval date." Her ringing concluding paragraph has been quoted many times over: "The interest in Zimbabwe [...] should, on this account, [...] be enhanced a hundredfold; it enriches, not impoverishes, our wonderment at their remarkable achievement: it cannot detract from their inherent majesty: for the mystery of Zimbabwe is the mystery which lies in the still pulsating heart of native Africa" (Caron-Thompson 198-99).

Today the superior archaeological endeavors of Randall-MacIver, CaronThompson, and their successors hold the ascendancy, so much so that Thomas $\mathrm{N}$. Huffman, an authority on Great Zimbabwe, did not include as recommended reading any of the disproved antiquarian theories in his Symbols in Stone (1987), a guidebook to the ruins.

Divergent opinions exist as to the decline or destruction of Great Zimbabwe. According to some local traditions, reported by Summers (Rhodesian Mystery 94-95; Ancient Ruins 167), "a horde of Angoni warriors under Chief Zwangendaba" destroyed the settlement. These Swazi warriors fled from Shaka and "spread their destruction" to Zimbabwe and across the Zambesi River to countries known today as Zambia, Malawi, and Tanzania. This displacement obviously refers to the mfecane of the early nineteenth century and does not accord with leading opinion 
on the matter. Most contemporary experts discount the possibility of a violent or abrupt end and date Great Zimbabwe's decline to between the late fourteenth and mid fifteenth century. They put forward that one or a combination of the following causes precipitated the polity's demise: climatic or ecological changes, changes in its internal or external commercial significance, or a downturn in its political or religious importance. Whatever the exact cause, "there are good reasons to suppose that it was the result of a planned, controlled, if not voluntary withdrawal of the people" (Garlake 110; see also Pikirayi 15053).

For a very long time, on the matter of Great Zimbabwe antiquarian studies held sway. At various times colonial, business, governmental, and administrative authorities all actively promoted this orthodoxy. For instance, Garlake observed that following exploration trips, sponsored by the British South Africa Company of Cecil John Rhodes, notions of colonial justification abounded with an almost emotional appeal to the idea of Phoenician colonization: "What the British Empire is to the nineteenth century, Phoenicia was to the distant ages" (H. A. Wilmot, qtd. in Garlake 65). At this time, in the late nineteenth century, Great Zimbabwe "quickly became a symbol of the essential Tightness and justice of colonization and gave the subservience of the Shona an age-old precedent if not Biblical sanction" (Garlake 65). ${ }^{8}$ In the 1930s, some indigenous nationalists even accepted that non-Africans forced the local populace to build the monumental structures and by the late 1960s, Rhodesian schools still taught Hall's "hypothesis of high antiquity," just as South African schools set du Toit's Di Koningin fan Skeba. Earlier guidebooks and the Official Year Book of Southern Rhodesia perpetuated these interpretations, bestowing on it "the cloth of orthodoxy" (Summers, Rhodesian Mystery 29). David Chanaiwa contended that as late as the 1970s, the "[Semitic] myth has become an essential instrument of colonial domination" (123). Furthermore, for some the mere idea of a mystery that has to be solved contributed to the complex's commercial value (Summers, Rhodesian Mystery 29).

The predominance of the antiquarian school clearly influenced Philander. His epic poem presupposes the Egyptian construction of Great Zimbabwe. Put quite simply: for a writer in search of a good story the antiquarians had better stories than the archaeologists did. The hypothesis of high antiquity provided plenty of possibilities-published historical intrigues, tales rich in variety—and histories that corresponded with Philander's interests in Egyptian, Greek and Roman antiquity In the words of Chanaiwa: "[T]he diffusionists (i.e. the antiquarians - HW) had a wealth of non-scientific sources - the Bible, rumors, second-hand information, and popular novels-upon which they relied" (65).

On the other hand, the alternatives were heavily criticized, far removed from the popular mind and where available, not readily accessible. The archaeologists reported their accounts as scientific, academic texts often in an unexciting, unembellished, professional manner. It was only in the early 1960s and 1970s when Roger Summers published his introductory overviews, Zimbabwe: A Rhodesian Mystery (1963) and Ancient Ruins and Vanished Civilizations of Southern Africa (1971), that the antiquarian position came to be challenged in the popular domain.

Knowledge of Great Zimbabwe as an indigenous community was not only actively discouraged while general published accounts of African polities, traditions and individuals were largely non-existent. British historian Trevor Roper's rather cynical comments-reminiscent of similar observations made by the 
philosopher Hegel—would have received several approving, if embarrassed nods among the colonial educated black elite in South Africa: "Perhaps in the future there will be some African history to teach. But at present there is none: there is only the history of the Europeans in Africa. The rest is darkness [. . . . And darkness is not a subject of history" (qtd. by Bruwer 140).

Philander at the time of writing had a choice of exciting, if conflicting, possibilities on Great Zimbabwe. A random survey of the available resource material before 1968, the publication year of Zimbabwe, suggests that the poet made an informed decision on the foundation of his epic's plot. He would have been knowledgeable about the work of the nineteenth-century Afrikaans writer S. J. du Toit whose Di Koningin fan Skeba was still available in modernized Afrikaans. In fact, in 1963 some of the Departments of Education in South Africa schools set a newly abridged version for its senior literature courses. Haggard's novels, King Solomon's Mines and She, were circulated widely, while the South African Library in Cape Town, a major research facility that Philander may have used, had some titles on Great Zimbabwe available, including Bent-the poet's most likely source-and Randall-MacIver as well as Patricia Stevens's Zimbabwe Culture: A Bibliography (1950) published by the University of Cape Town. At the time of the preparation of the epic poem, A. J. Bruwer had just published his Zimbabwe: Rhodesia's Ancient Greatness (1965), a continuation of the antiquarian thesis, while Summers's Zimbabwe: A Rhodesian Mystery was reprinted in 1965. Both these texts present relatively full accounts of the "Zimbabwe controversy," so that if Philander consulted them he would have had a good grasp of the debate. ${ }^{9}$ Given the availability of source material we may assume that Philander, in the face of the archaeological breakthroughs of Randall-MacIver and Caton-Thompson, made a deliberate choice to draw on the Semitic myth or the antiquarian thesis as the foundation for his epic poem.

The central theme in the epic Zimbabwe is the rise and decline of a technologically advanced society, an exploration of its options for survival in a rough neighborhood and the limitations of a deficient value system. The antiquarian thesis provided Philander with a useful societal organization in which he could explore these ideas fictionally. He constructed a social order characterized by the unequal representation of social forces:

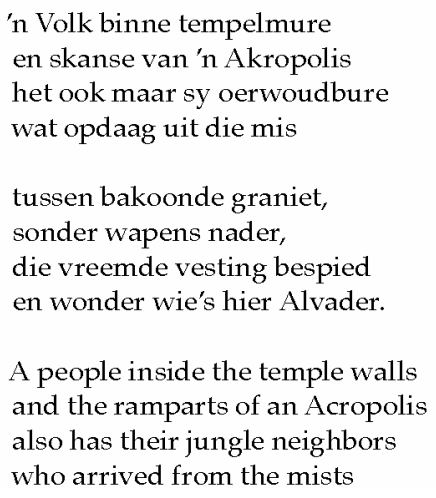


between furnaces granite

approach without weapons

to inspect the strange fortress

and ponder who is the Almighty here? (13)

The remainder of this article concentrates on Philander's rendering of these social forces - the "people inside the temple walls" and "the jungle neighbors"—and concludes with a political reading of the poem Zimbabwe.

Philander's Zimbabwe society is stratified along lines of creed, custom, gender, heritage, and occupation. ${ }^{10}$ Inside the walls of Zimbabwe are the "long black haired" (i.e., Egyptian rather than European) settlers from the north. Hair, especially hair texture, serves here as a key signifier for colonial and racial difference (see hooks 63-66). In this theocracy the priests implementing the laws of a priest-king are at the pinnacle, supported by eunuchs who guard the society's maidens or executioners who carry out the sacrifices that form part of their religious practices. ${ }^{11}$ There are hunters, warriors, and the gatherers of provisions and at the bottom the slaves who are the water bearers and builders of the temple, the citadel and the walls. Philander's focus is largely on the women, and particularly his main character, Ulali. This society that justifies male dominance as well as sexual violence against women-this phallocracy-also objectifies them as "die uitgesoektes in die fuik" 'the chosen ones in the coop' (46). The women are beyond the reach of those outside the walls of the settlement since they procreate "die ras" 'the race' (16) and in times of profound crisis the sacrifice of a woman amounts to the highest possible offer. Outside the high walls of this secluded society are the aboriginal forces mustering against them: those progressively called the "jungle neighbors," "the children of the reed," "the enemy," the barbarians," and "the evil men"12

In this context it is instructive to read aspects of Frantz Fanon's classic text on decolonization, Les damnés de la terre (translated as The Wretched of the Earth, 1961, 1965), with Philander's Zimbabwe. With regard to the settler-aboriginal relationship, Fanon wrote that "[t]he settler and the native are old acquaintances [. . .] for it is the settler who has brought the native into existence and who perpetuates his existence. The settler owes the fact of his very existence, that is to say his property, to the colonial system" (28). The differences between the settlers and the aboriginals in Zimbabwe are based on a range of distinctions: the main distinctions being technological advancement, religious practices and somatic differences.

The settler-aboriginal distinction externalizes an underlying technological divide. The settlers imported from their distant civilization techniques for mining and smelting iron and gold, construction expertise to dress stones and split granite, and architectural skills to plan and build a temple and a fortress, the Acropolis. ${ }^{13}$ If those inside the walls recall the settlers of Fanon's manichean colonial world-"a world which is sure of itself" - those outside are the colonized other, often treated "as an inferior but [. ..] not convinced of his inferiority" (Fanon 40-41). Compared to the Zimbabwe civilization founded on advanced technology and "vernuf" 'ingenuity' (16), the aboriginal world is deficient, primitive, and "vermuf" 'musty' (16). The omnipotent narrator in the poem implies that these differences are the result of colonial greed: 
Hulle wou alleen die weelde dra, veilig agter klipmure bly

en as vreemde stamme kom vra

het hulle die poorte toé gekry;

moes tevrede wees

met mandjies vleg.

Met dik-dikkies kerf en wildebees

kom mens glo ook in Afrika reg.

They wanted to wear the wealth alone,

live safely behind the stone walls

and when strange tribes came to ask

they found the gateways closed;

[they] had to be satisfied

with basket weaving.

Apparently by carving small dik-diks [antelope] and wildebeest

the people in Africa also cope. (17)

Philander culled a distinctive feature of his settler civilization, namely, their phallic or fertility worship, from the antiquarians' writing on Phoenician religious practices. For the antiquarians phallicism represented a sophisticated, reflective and aesthetically conscious tradition. ${ }^{14}$ In ancient religions, some antiquarians assert that fertility cults represented "new and advanced ideas," for "[w]hen these marvellous people, these industrious people, these dynamic and intelligent people, the Phoenicians, put their grain into the soil, they had their gods and goddesses, to whom they look for a good harvest, prominently in mind" (Bruwer 51, also 56). Philander described several of these fertility rituals and practices in his epic poem, for example:

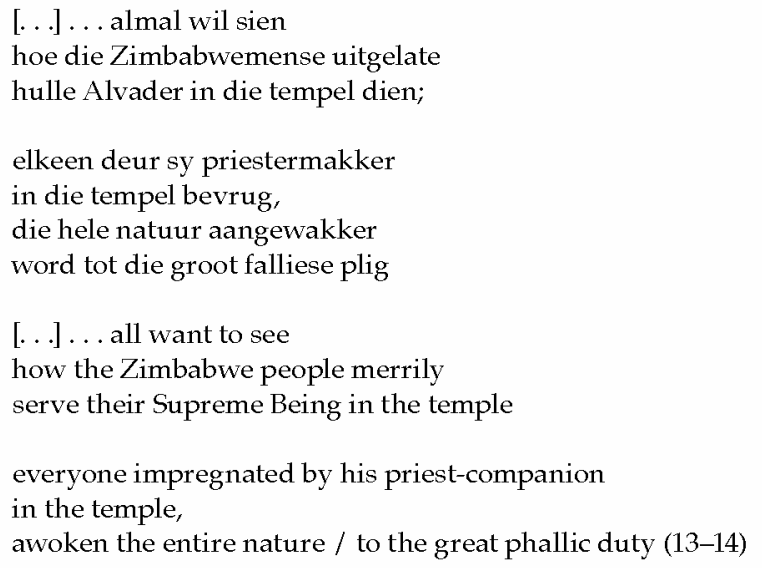


Sy bly'n goeie moeder

al het ek uitgevind

sy was'n loeder

en ek... haar loederskind

She was a good mother

even though I found out

that she was a whore

and I... her whore's child (25)

Philander's text is replete with references to phallic rituals and ceremonies, including the purported sacrifice of the main character, Ulali's only son (35). Compare these following descriptions to gauge how closely he captured these rituals quoted above. With regard to the role of the priests Bruwer wrote: "In the necessary ritualistic ceremonies connected with religions based on fertility cult, the king personified or represented god, or goddess, at first. Later his place was taken by the high-priest" (52). With respect to the place of sexuality and sacrifices, Bruwer declared, "Temple prostitution made possible the consummation of the symbolic union of the sun-god and mother earth. Sacrifices appeased the gods, and took the form of self-mutilation, and the sacrifice of the first-born, or of an only child [. . .] Wild orgies and frenzied inspiration often accompanied these rites" (52).

The phallus may be a sign of generative power but it is primarily the symbol of patriarchy, represented in the monoliths, but especially in the prominent tower, in Philander's words, "'n keëlvormige klipkloot," 'a conical stone testis' (12). Zimbabwe culture put women on the proverbial pedestal, i.e., at once idealized and oppressed, for instance the soapstone bird effigies carved in the temple represent women and are installed in aesthetically pleasing but confined surroundings (see also Bruwer 61, 63). ${ }^{15}$ Compare this quatrain where the female symbols are associated with the temple, skillfully finished off with chevron edging, the very space in which the women forcibly endure the demands of the priests: "Ons het seepsteenvoëls gehou,

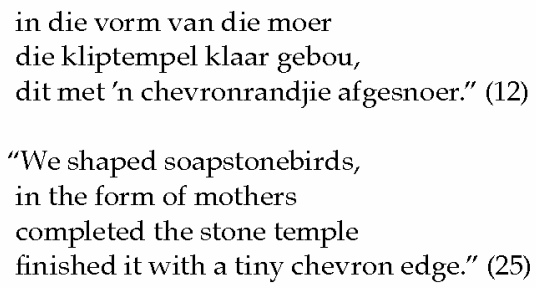

The Zimbabwe women are compliant and fatalistically submissive: "[. . .] daar's geen behoeders / in die tempel teen die owerspel" '[...] there's no minder / in the temple against the adultery' (22). They are kept separately on the Acropolis, guarded by eunuchs and taken at a time, unknown to them, taken through a subterranean passageway, a "sinapsis van die pyn" 'synapse of the pain' (23), to the temple where the priests, in the name of their religion violate them. At the same time, in relation to the core tension of the text, i.e., the conflict between the colonial settler and the aboriginal mass, the Zimbabwe women are also objects of 
desire for the approaching men outside the walls. These women as the custodians of the Zimbabwe people's racial purity are declared to be beyond the "jungle neighbors's" reach:

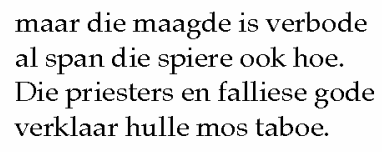

Die wet van die priestervors

wat hierdie ras moet suiwer hou,

sê: net' $n$ langhaarkind kan die bors

vat van 'n Zimbabwevrou. (16)

but the maidens were forbidden

even if the muscles are taut.

The priests and the phallic gods / declare them taboo.

The law of the priest king

that this race must be kept pure,

states: only a long-haired child may touch

the breast of a Zimbabwe woman. (25)

In the battle for political supremacy, the aboriginals consider the women part of the spoils of war and throughout the text their expressed demands include the right to sleep with the settler women, i.e., Philander's rendering of the sexualized savage colonial stereotype and the age-old fantasy for the unattainable other. "The settler's world," Fanon once said, "is a hostile world, which spurns the native, but at the same time it is a world of which he [the native- - HW] is envious" (41). This envy has its origins, according to Fanon, in the property and social relationship between settler and aboriginal: "The look that the native turns on the settler's town is a look of lust, a look of envy; it expresses his dreams of possession - all manner of possession: to sit at the settler's table, to sleep in the settler's bed, with his wife if possible" (30).

Key to these confrontations in Zimbabwe is the way in which the conflict progresses from initial curiosity, friendly engagement to violent opposition. At first the "jungle neighbors" are unarmed and inquisitive about the religious practices of the strangers. The next approach from "the children of the reed" is an invitation to dance and to share with the settlers. The settler authorities rebuff these friendly gestures and their actions further inflame the tensions between the Zimbabwe people and the aboriginal inhabitants, "the barbarians." Gradually, the settler-aboriginal relationship disintegrates. Compare this progression in the following selections (taken from successive stages in the poem-the beginning, the middle and the end):

Die opperhoof van die kraal

wou sy mahoniebome verpag

vir die smeltkroes se praal

as die Zimbabwemeisies lag. 
The chief of the kraal

wanted to barter his mahogany trees

for the riches of the crucible

when the Zimbabwe girls laugh. (15)

The initial exchange and barter give way to more insistent demands with overt threats of violence:

en weer die gloed van 'n vuur gewaar

wat rondom ons granietmure brand

die uitroepe hoor van die barbaar:

"Ons laat die vesting in kole beland;

wil die goud van die smeltpotte hê;

ons merimba's ook binnensmuur hoor

en met julle vrouens onder die sterre lê

tot die xilofoonslaner sy slag verloor."

and again saw the glow of a fire

that burns around our granite walls

hear the shouts of the barbarian:

"we will put the fortress to fire;

[we] want the gold from the crucible;

hear our marimbas inside the walls

and lie down with your women under the stars

until the xylophone player loses his touch." (44)

Towards the end of the poem the unabashed threats of sexual predation dominate:

\author{
Toe dreun hulle naglied \\ binne die mure: \\ "Ons soek die kokkewiet \\ In die vroemôre-ure; \\ soek steeds nog \\ die seksuele \\ binne die trog \\ van 'n vrou se onderdele; \\ moet beur teen die hang \\ waar die uitverkorenes woon \\ tot ons later wang-aan-wang \\ in die vreugdes van 'n klein sikloon \\ na asem snak \\ met die ritteltit \\ voor als afknak \\ en ons op ashope sit."
}

Then they hear the song at night Inside the walls: 


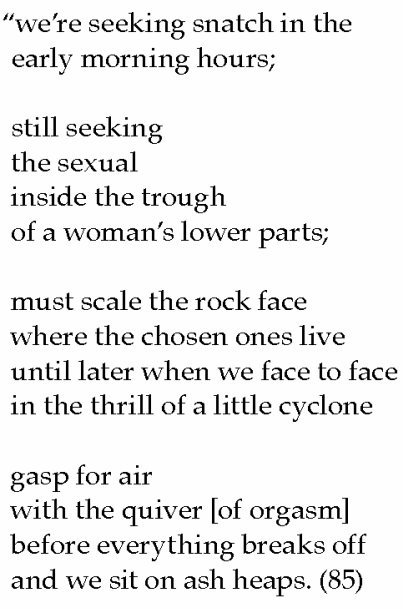

What starts out as inquisitive merry-making, develops into protest against colonial greed and social separation that eventually ends up in the undefined "die doelgerigte / planne van die mans" 'single-minded / plans of the men' (87). Given the context of the colonistcolonized paradigm, the understatement of colonial violence against the aboriginals in Zimbabwe, i.e. the violence against which the aboriginals react, results in the obvious conclusion that the aboriginals' violence turns to gratuitous pillage and therefore wanton terrorism.

For the Zimbabwe civilization the submission of their women holds far-reaching consequences. These women faced with persistent threats and the likelihood of rape and plunder commit mass suicide to save their honor at the very moment that the aboriginals breach the defenses of their settlement. In the Judeo-Christian sphere that Philander might have been conversant with this scenario obviously recalls the famous event on a hill at the Dead Sea town of Masada in 66 CE where its inhabitants committed mass suicide rather than surrender to an invading Roman army, an act constructed later on as an act of supreme Jewish martyrdom (see JewishVirtualLibrary.org). In the context of the settleraboriginal binary that Zimbabwe evokes, this act of martyrdom prevents any possible miscegenation, between the settlers and aboriginals. It puts an end to any possibility of the settler garrison's continued existence. In short: martyrdom excludes the possibility of compromise and with it continued, if altered, existence. In Fanon's words, the "idea of compromise is very important in the phenomenon of decolonization [. . .]. Compromise involves the colonial system and the young nationalist bourgeoisie at one and the same time" (48). Without any compromise the eventual cost for the maintenance of a cherished value system, property or a set of social mores is enormous. The incapacity (and suggested slaughter) of the men and the mass suicide of the women imply the total destruction, the apocalypse, of the settler civilization.

When at the very last moment a child is born, the women's suicide turns out to be an act of near extinction, rather than annihilation. However, the settler civilization remains destroyed. The newly born settler child-without the cultural, social, or technological trappings of a settler civilization-faces an uncertain future among the aboriginals: 


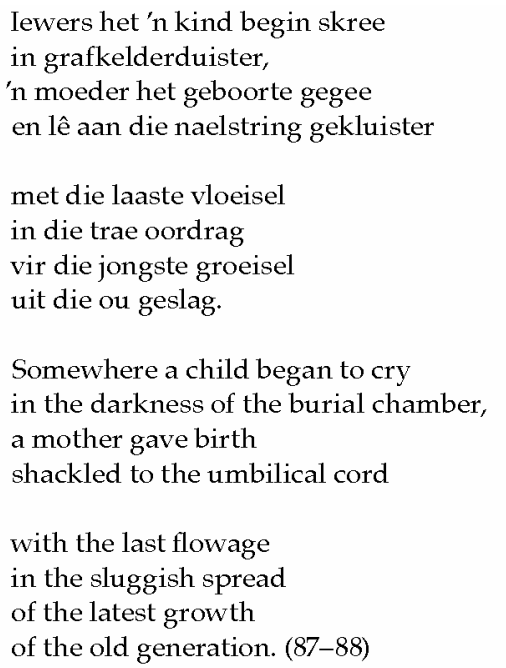

This moment offers the enticing possibility of reading the conclusion in terms of the inevitability of the eventual miscegenation of descendants of the Zimbabwe people, even if the settlers's near annihilation postpones it to a subsequent generation. Another possibility is obviously that of the Tarzan myth, following Edgar Rice Burroughs's Tarzan of the Apes (1914), where the eponymous character, being orphaned, grows up among apes, and through self-development advances from primitive man to nobleman, recovering the culture of his parents.

Although the settler perspective and in particular Ulali's voice predominate in Zimbabwe there are other voices present, not least the voices of those outside the elevated stone structures. Whereas the voices of the dominant settler characters are individualized these voices are nameless, often presented as the single voice of an inquiring or menacing horde. It is an undifferentiated, collective voice, for example "We, children of the reed" (15), "Come dance with us" (15), "We will burn the fortress down" (44; emphasis added). As indicated earlier, the aboriginals formulate their demands unequivocally and there are just the slightest of hints that these demands are the result of economic (or political) restrictions, i.e., "They (the settlers) have confined the folk culture / to wood, ivory and clay" (emphasis added):

Hulle het die volkskultuur

beperk tot hout, ivoor, klei

mondbogies, dolosse, vuur,

solank dié goud vir hulle bly.

They confined the folk culture

to wood, ivory, clay

mouth-organ, dolos [knuckle-bone], fire

as long as they control the gold. (17; emphasis added)

Fanon wrote a justification for revolutionary violence, or more precisely counterviolence; violence "represents the absolute line of action" (67): "It frees the 
native from his inferiority complex and from his despair and inaction; it makes him fearless and restores his self-respect" (74). Although in Philander's epic there are hints of the settlers' differentiated treatment or enforced economic and social restrictions of the aboriginals, very little is actually revealed. What comes to the fore more forcefully are the demands of the aboriginals, mostly cast in naive, and limited, ways-eventually ending in the demand for "the trough / of a woman's lower parts."

In the preceding discussion it became clear that the epic poem uncovers the fault lines of a foreigner settled society. In Philander's rendering, Zimbabwe becomes the tale of abortive colonization - mainly brought about by the settlers' insularity, their inability to read the signs of history, and their failure to survive through strategic compromise. In his earlier collections of poetry he exhibited a wide-ranging understanding of the histories of repressive social systems. In Uurglas, he explores ancient master-slave relationships, the nature of repression and the inevitability of social change. Philander wrote Zimbabwe following the wave of the decolonization of African countries in the mid-twentieth century.

By the end of the 1960s, most African countries had gained independence. In southern Africa, the British protectorates of Southern Rhodesia, Northern Rhodesia, and Nyasaland (later: Zimbabwe, Zambia, and Malawi, respectively) formed the colonistdominated, semi-independent Federation of Rhodesia and Nyasaland, or the Central African Federation, in 1953. With the onset of decolonization in other African countries the "almost universal African opposition" ended the Federation in 1963. Zambia and Malawi came under the control of indigenous parties, but in Southern Rhodesia, the white settlers resisted this trend. Ian Smith, the last prime minister of Rhodesia, unilaterally declared "independence" in 1965, a step that would lead black nationalists to engage in protracted guerrilla warfare (Iliffe 248-49). South Africa gained independence in 1910, but successive postindependence government policies favoring white political interests increasingly destabilized the country. By the mid-1960s, the National Party government resorted to repressive measures to keep internal black resistance at bay.

Philander's choice of Great Zimbabwe in his epic poem is apposite. Garlake remarked that at the beginning of the twentieth century the settlement became a "symbol of the essential Tightness and justice of colonization" (Garlake 65). The perceived parallel between Great Zimbabwe and white settlers in southern Africa is therefore not gratuitous. Take for example the case of A. J. Bruwer, a political economist, who dedicated his book Zimbabwe: Rhodesia's Ancient Greatness to a defiant Smith, the Rhodesian prime minister. In 1965, comparatively late in the debate on the origins of Great Zimbabwe, Bruwer still advanced the continuity of a settler and industrially advanced civilization from its formation to the establishment of an industrial state in the 1960s. He is disillusioned with the termination of the Central African Federation at the end of 1963 and wary of the increased confidence of black people:

Was this holiday rush of the [white-HW] Rhodesians one way of closing their eyes to the toppling of their ten year old Federation dreams, and was the popularity of the famous ruins an unconscious tribute to those pioneers, who, many centuries ago, put up their gigantic structures with bitter toil, sweat and tears, 
only to disappear like mist before the morning sun? And did they have at the back of their minds the likely fate of those whose dynamism brought forth the giant Kariba, a Kyle Dam, giant copper and asbestos industries, inspiring roads, far-flung ranches, and what not? (3)

In Zimbabwe, the contemporaneity that Bruwer suggests is obvious. In the crudest of interpretations one may read the epic poem as a commentary on Ian Smith's defiant resistance to pending black rule or apartheid South Africa: the self-centeredness and selfimposed insularity of the settler society. Most Afrikaans literary critics explicitly recognized the political analogy and some even commented on it: "Wat met die Zimbabwe-mense in hulle trotse afsydigheid van die omringende stamme gebeur, is wesentlik ook die situasie van die blankes in hul verhoudmg tot die ander rasse in SuidAfrika" 'What happened to the Zimbabwe people in their proud insularity with the adjacent tribes is essentially the situation of whites in their relationship to other races in South Africa' ( Kannemeyer 215; see also Kok 87).

Philander speaks to the fundamental inequities of colonial societies as well as the need for the resolution of the inevitable conflict that such political systems generate. Throughout the text the pertinent theme is the settler-aboriginal tension with an overlay of the precarious position of settler women. Earlier I read the mass suicide that Ulali, the main character in Zimbabwe, instigates as a response to the impending attack of the aboriginals. A feminist reading may interpret this response is a reaction borne from social powerlessness where the women in committing suicide use the only power available them. Read from a racial-political paradigm, however, the protection of racial purity is at the heart of the defense of the Zimbabwe complex. In this the Zimbabwe women are the bearers and guardians of their community's racial purity Philander writes as a political gradualist who recognizes the technological advances and permanency of colonial settlement but is not totally convinced of the readiness of the colonized to govern. In this sense Zimbabwe is a prophetic text: an expansive warning of the political outcomes should there be no change in the settlers' mentality; a call for gradual political recognition and social integration

Although biological racism was not explicitly part of the South African National Party policy, the historian William Beinart states that the "irreducible aims" of apartheid was the "'maintenance and protection' of Afrikanerdom, white power and the white race" (147). National Party propaganda exploited white fears of "miscegenation." In 1948 and in several elections thereafter the political mantra of "Would you let your daughter marry a black man?" formed the core of the apartheid message. "It played on deeply set white notions of purity, especially that of white women, and Social Darwinist fears that mixing would result in racial decline" (Beinart 147). On this reading I suspect that Zimbabwe becomes a poetic act of protest against the Rhodesian-type independent state, and more particularly the apartheid state. Philander takes the Semitic myth on board and subverts it through the exploration of the dire consequences of political insularity, the inability to compromise and the myth of racial purity. His text becomes a gentle reminder to his white Afrikaans compatriots of the long-term consequences of the South African government's racial policies. 
Philander comes across as a political moderate in an environment that

demands unambiguous political choices. "Dis die ongelukkigheid hier," he said in a newspaper interview. "Almal wil pal he jy moet kant kies. Hulle wil jou woorde peil. Hulle wil pal he jy moet oplossings bied. En wie is jy nou om dit te kan doen?" 'That's the problem here. Everybody always wants me to choose sides. They want to gauge your words. They want you to come up with solutions. And who are you to do that?' (Philander, qtd. in Rautenbach en Retief 20). Philander's ambivalence concerning apartheid is significant. His vacillation should be seen against the background of the choices people from similar backgrounds made in the 1960s and 1970s. The antiapartheid political pressures were such that several political organizations embarked on programs of violent resistance. In Cape Town, a small band of radical coloured teachers-many from rural backgrounds, like Philander-even waged a sabotage campaign. In October 1963, these members of the National Liberation Front, also known as the Yu Chui Chan Club, were found guilty of sabotage and terrorism. The saboteurs were sentenced to long periods of imprisonment. For political conservatives the option was to support the National Party government's grand apartheid policy. This implied the creation of a separate political structure, the Coloured Representative Council (CRC), which administered the affairs of coloured people. The majority of coloured people mistrusted this body and its councilors and CRC never enjoyed significant acceptance.

Philander's position is that of the vacillating black moderate who cannot get himself to join the radicals' claim for immediate transfer of power or engage in sabotage. At the same time, he cannot completely be at one with the conservative's political acquiescence that would see him separated and isolated. His economic and political position further complicated his personal decision-making. Philander was inscribed within the apartheid system: he was a principal of an urban high school when teachers who were politically outspoken would have found it difficult to secure such sought-after administrative positions. He co-authored primary school social science textbooks at a time when the ruling party's apartheid policy regulated even the setting of such texts. He also presented a radio program aimed at the "coloured population group." Left-wing activist groups generally saw the radio program as a pro-apartheid activity, i.e., a way of "fostering" and "creating" the "coloured group."

An impassioned paragraph in a newspaper article written almost thirty years after his departure from South Africa reveals Philander's perspective on these matters:

\footnotetext{
Ons was saam met hom in sy Groot Trek, het saam met hom die skynbaar onoorkombare berge te bowe gekom. Saam met hom het ons die angste daarvan belewe en oorlewe. Ons was ook saam met dié van hulle wat agtergebly het in die Kolonie, veral in die Boland, en het sy taal deur die koloniale jare en daarna help bewaar en vorm toe dit kombuisgebonde ' $n$ verstoteling was. Ons was en is nog steeds deel van sy ganse lewe en het gedeel en deel nog steeds in al sy aardse en geestesgoed.
}

We were together on his Great Trek; with him (the Afrikaner's-HW) we overcame the apparently insurmountable mountains. With him we endured and overcame anxieties. We also stayed behind with those who remained in the 
Colony, especially in the Boland, and through the colonial years we preserved and shaped his language when it was restricted to the kitchen and an outcast. We were and remain part of his whole life and shared and are still sharing in his earthly and spiritual possessions. (Philander 13).

In the confined circumstances of apartheid South Africa Philander cultivated longstanding friendships with Afrikaner intellectuals who were critical of National Party apartheid politics, writers like Jan Rabie, Uys Krige, Abraham de Vries, and social scientists like H. W. van der Merwe and Nic Olivier, among others (see Peter Philander). Under ordinary circumstances, Philander's public expression of kinship with people from the same class, social or cultural standing would have been natural, uncomplicated, and unproblematic. In apartheid South Africa, his intellectual and social, if not political, dilemma was that his linguistic kin repressed and separated him. He found political rejection and only limited cultural acceptance, mostly on the intellectual, dissident fringes of Afrikaner society.

Philander's expressed cultural and social kinship underscore his ambivalent treatment of the politics of colonialism in Zimbabwe. His difficulty in formulating a coherent oppositional voice, a voice that goes beyond the brutal sexual stereotype as perceived by the settler, points to this ambivalence. Just as his understatement of colonial violence or his difficulty at exploring the nature of colonial violence results in an unavoidable contradiction. He writes a text from the point of view of the colonists and explores their moral and social dilemmas while in contrast the colonized oppositional voice remains at best sketchy and stereotypical. He wrote a text that serves as a dire prophetic warning for the settler that racial pride only postpones the inevitable-the colonized's future march from outside the colonial wall. However, the alternative, the possibility of co-existence and the oppositional voice of "the children of the reed," remains collectivized, naïve, and limited. For Philander, the political moderate and gradualist, the abiding difficulty is breaching his bands of social and linguistic kinship and imagining a postcolonial future.

\section{NOTES}

1. These events are open to a range of inferences on the motives for awarding and accepting these decorations. Philander received these honors at the height of the National Party's apartheid policies. For instance, in 1963, at the time of his award the SuidAfrikaanse Akademie vir Wetenskap en Kuns only allowed Afrikaner or white Afrikaans academics, scientists and writers as members. This meant that Philander, as a person classified coloured, could not be admitted as a full or associate member. Philander is silent on the reasons for his acceptance of the award under such conditions, and virtually no response from the "coloured community" could be traced. Earlier, a similar award to S. V. Petersen was met with "our heartiest congratulations" from at least one (coloured) newspaper columnist (Van der Ross 53). An interview many years later is revealing as to Philander's reaction to his more critical interlocutors: "Daar is destyds na my en S. V. verwys as die 'uitverkopers'; dat ons 'heul met die witman'" 'In the past there was referred to me and S. V. [Petersen] as the "sell-outs"; that "we collaborated with the white man'"Vermaak 2). The episode in part reveals Philander as a political moderate, someone who the Afrikaner cultural and political establishment might have regarded as nonthreatening.

2. A sign of the (continuing) difficulties of racial nomenclature in South Africa is the pronouncement in 1960 by the eminent Afrikaner poet N. P. van Wyk Louw on 
the terms Kleurling, kleurling, and bruinmens: "Ek vind 'Kleurling' (met of sonder hoofletter) 'n nare woord, met plantasie- en koloniale bysmake-en dalk nie eens goeie Afrikaans nie, 'n geïmporteerde woord; en ek verkies die woord 'bruinmens' wat ek as kind uit die mond van die bruinmens self leer gebruik het" 'I regard "Kleurling" (with or without the capital letter) as an awful word, reeking of plantation and colonial connotations - and perhaps not even good Afrikaans, an imported word; I prefer the word "bruinmens" that I have learnt from the months of the bruinmense themselves' (Louw vi).

3. All three these statements bear the hallmarks of the political sensitivities and parlance of their respective historical periods. One Afrikaner critic regarded as the onset of writing by poets classified coloured, especially Petersen, in the 1940s and 1950s as "die roue krete van opstand teen 'die vloekstraf van 'n donker huid'" 'the raw cries of revolt against the "curse of a dark skin" or "vir die eerste keer in ons taal die skrynende leed tot uiting dring van hulle wat die slagoffer is van die sondes van die vaders" 'for the first time in our language the grim grief of those who are the victims of the sins of the forefathers are forced to the fore' (Dekker 292). The use of the genitiveour language or our poetry - reveals to some degree exclusivist notions of Afrikaner nationalist custodian- and ownership of the Afrikaans language. At the beginning of the twenty-first century notions of a shared culture and greater commonality among speakers of Afrikaans have replaced in some quarters such tacit earlier declarations of cultural exclusivity. It is therefore possible for a literary critic in 2005, even if his view is an overstatement, to conclude without any racial qualification that Philander was "an indispensable voice in the Afrikaans literature."

4. There are two divergent references to "little cyclone" in the poem. The first refers to the whirling axe of the executioner in the following quatrain "tot die byl soos 'n skroef / in 'n windkring gaan / voor hy verstroef / weer stil kom staan" 'until die axe swirls like a propeller / in a circle of wind / before he eases up / [and] come to a standstill' (75) and the second to orgasm, especially when voiced by an invading band of aboriginal warriors: "(ons) moet beur teen die hang / waar die uitverkorenes woon / tot ons later wang-aanwang / in vreugdes van 'n klein sikloon // na asem snak / met die ritteltit" '[we] must scale the rock face / where the chosen ones live / until later when we face to face / in the thrill of a little cyclone / gasp for air / with the quiver [of orgasm]' (85). Philander is notoriously difficult to translate. He uses fixed poetical forms, mostly rhyme schemes and the abundance of obsolete vocabulary and expressions complicates his poetry. My translations are therefore mere approximations.

5. Zimbabwe is a Shona word etymologically derived from dzimba dza mabwe (houses of stone). Another explanation is that the word derived from dzimba woye (venerated houses) in reference to the chiefs' houses or graves. Today the term denotes mainly the country by that name, whereas the archaeological term, Zimbabwe, refers to stone buildings of a particular origin and "Zimbabwe culture" refers to the five southern African political formations, i.e., Mapungubwe (1040-1270), Great Zimbabwe (12701550), Mutapa (1450-1900), Torwa (1450-1650), and Rozvi-Changamire (1680-1830). The discerning feature of these settlements is the presence of stone buildings in a variety of building styles. Great Zimbabwe refers to the ruins found close to the provincial town of Masvingo, southeastern Zimbabwe (see Garlake 11; Pikirayi 1-3, 13). In this article Philander's epic poem Zimbabwe is italicised since it is a book-length publication.

6. Bent (118 ff.) related most shaft-like, rounded, circular, or monolith structures at Great Zimbabwe to Phoenician phallicism. Bruwer, an ardent supporter of Bent and Hall, explains phallicism as "the worship of the reproductive powers of nature as symbolised by the male reproductive organ, the phallus. The aim of the worship was to safeguard the numbers and the food of the tribe" (51n). 
7. An indication of the persisting attractiveness of the antiquarian thesis is that as recently as 1977 some lay commentators still insisted on promoting it, even in the face of archaeological evidence to the contrary (see Bruwer and Mallows).

8. The prevalence of this line of thought even in the 1960s can be deduced from Bruwer's pronouncement when he expresses his admiration for the Phoenicians: "The Phoenicians pioneers always reminds me of the Voortrekker Boers of South Africa among whom a saying is supposed to have originated: A Boer makes a plan', "n Boer maak 'n plan:' they had to, in order to survive" (32n; emphasis in original). Bruwer's text abounds with implications that aboriginal Africans could not have constructed Great Zimbabwe, for instance: "The Bantu or Negro never used stone for building on an intelligent level. But who, who then, put up these hundreds of scientifically built stone structures? Who did the designing and supervision?" (10; emphasis in original).

9. Casual meetings with guides at the ruins would have given the poet an idea of the differences in interpretation on the meaning of the settlement. Philander and his family visited Great Zimbabwe in the early 1960s and some of the guides they encountered would certainly have advanced views supporting the perspective that indigenous people built the complex (see Peter Philander 186). A contemporaneous report by Bruwer who visited the ruins in 1963, offers this dismissive but highly instructive account of the views of the black guides: "I could enjoy my bed, the beautiful Rhodesian moonlit night, and the fantastic memories of the sights I had seen that day-also the somewhat amusing and boastful words of one black guide to his group of black tourists on the highest point of the Acropolis: As history teaches us, the Shonas built. . .', and the look the another black guide of a group of black tourists threw patronisingly over his shoulder as us, while he was 'explaining' the architecture of the Acropolis to his spellbound audience: 'now, here is a lintel just like in any modern house . . .' They were in smiling mood; they were in magnanimous mood; they were sure of themselves - of Albion" (Bruwer 3, emphasis in original).

10. Contemporary archaeologists hold that the "settlement was the home of prestigious individuals and their lineage mates and clients" with the hierarchy of a traditional, mercantile or agricultural elite occupying the highest points of Great Zimbabwe, the great enclosure and the hill complex (Pikirayi 132-40).

11. In this regard Philander might even be following Bruwer, who hold that "when Phoenician supremacy became well established and when the Baal-Astarte religion got a firmer hold on the people as a result of a huge hierarchy of priests, more severe sacrifices were demanded - an only child, for example, or the first born, had to be sacrificed in a spirit if the greatest stoicism, as otherwise the sacrifice would be of no avail" (55).

12. The description "kinders van die riet" 'children of the reed' recalls the Afrikaans writer Eugene N. Marais's short story "Klein Riet-alleen-in-die-roerkuil" (Little Reedalone-in the-whirlpool). More pertinent, though, may be the suggestion contained in the phrase of the southern African custom of the reed dance where the Swazi (or Zulu) king selects a bride from among maidens carrying reeds. The Swazi reference is apt since one of the possibilities for the destruction of Great Zimbabwe is an attack by the Swazi king, Chief Zwangendaba.

13. In contemporary writing the "the Hill ruin," the "Hill fortress," or "the hill complex" are used, rather than the Grecian "Acropolis," conceived by Bent.

14. Randall-MacIver intimated on the matter of phallic worship that "these negroes [the builders of Great Zimbabwe-HW], like all other negroes, revelled in obscenity, is probable enough" (Randall-MacIver 73). Today, contemporary writers such as Garlake and Pikirayi are less inclined to these suggestions; some attach agricultural symbolism to these towers, for example, as symbolic grain bins.

15. Pikirayi (135-36) summarized the findings of contemporary authorities on the soapstone bird effigies and came to the view that these were unique to Great Zimbabwe 
but that their symbolism is unclear; that they "appear to have served as spiritual or political symbols [. . .] [and that] [t]he consensus opinion places them in the African worldview as symbols of the mediating power of the chiefs."

\section{WORKS CITED}

Beinart, William. Twentieth Century South Africa. 1994. Oxford: Oxford UP, 2001.

Bent, J. T. The Ruined Cities of Mashonaland. 1892. Bulawayo: Book of Rhodesia, 1969

Bruwer, A. J. Zimbabwe. Rhodesia's Ancient Greatness. Johannesburg: Keartland, 1965.

Bryant, A. T. Bantu Origins. The People and Their Language. Cape Town: C. Struik, 1963.

Caton-Thompson, G. The Zimbabwe Culture. Ruins and Reactions. Oxford: Clarendon, 1931.

-The Zimbabwe Culture. Ruins and Reactions. 1931. Oxford: Frank Cass, 1971.

Chanaiwa, David. The Zimbabwe Controversy: A Case of Colonial Historiography. Syracuse: Syracuse U (Eastern Studies Program), 1973.

Cloete, T. T, A. P. Grove, J. P. Smuts, and E. Botha.. Die Afrikaanse literatuur sedert Sestig. Goodwood: Nasou, 1980.

Dekker, G. Afrikaanse literatuurgeskiedenis. Kaapstad: Nasou, s.a. [1966?].

du Toit, S. J. Die koningin van Skeba. 1921. Kaapstad: Nasionale Boekhandel, 1963.

. Di koningin fan Skeba of Salomo syn oue goudfelde in Sambesia. 1898. Kaapstad: African Uitgewers, 1998.

Fanon, Frantz. The Wretched of the Earth. Trans. Constance Farrington. London: Penguin, 1982.

Garlake, P. S. Great Zimbabwe. London: Thames and Hudson, 1973.

Haggard, H. Rider. King Solomon's Mines. 1885. Oxford: Oxford UP, 1989. She. 1887 Oxford: Oxford UP, 1991.

Huffman, Thomas N. Symbols in Stone. Unravelling the Mystery of Great Zimbabwe. Johannesburg: Witwatersrand UP, 1987

--------. Mapungubwe: Ancient African Civilisation on the Limpopo. Johannesburg: Wits UP, 2005.

hooks, bell. Sisters of the Yam: Black Women and Self-Recovery. Cambridge: South End, 2005.

Hugo, Daniel. "P. J. Philander (1921-)." Perspektiefen profiel - 'n Afrikaanse literatuurgeskiedenis Deel 3. Ed. H. P. van Coller. Pretoria: Van Schaik Uitgewers, 2006. 401-08.

lliffe, John. Africans. The History of a Continent. Cambridge: CUP, 1995.

JewishVirtualLibrary.org [O] "Masada: Desert fortress overlooking the Dead Sea." http:// www.jewishvirtuallibrary.org/jsource/Archaeology/Masadal.htmlAccessed23 Mar. 2006.

Kannemeyer, J. C. Geskiedenis van die Afrikaanse literatuur. Band 2. Pretoria: Academica, 1983.

Keane, A. H. The Gold ofOphir. London: Edward Stanford, 1901.

Kok, F. J. "Die stem van die Bruinman in die Afrikaanse poesie." Unpublished MA thesis. Potchefstroomse U vir Christelike Hoer Onderwys, 1976. 
Lindenberg, E., et al. Inleiding tot die Afrikaanse letterkunde. 1965. Pretoria, Kaapstad: Academica, 1980.

Louw, N. P. v. W. "Voorwoord." Die opkoms van ons derde stand. D. P. Botha. Kaapstad: Human and Rousseau, 1960. v-X.

Mallows, Wilfrid. The Mystery of the Great Zimbabwe. The Key to a Major Archaeological Enigma. London: Robert Hale, 1985.

Pikirayi, Innocent. The Zimbabwe Culture. Origins and Decline in Southern Zambesian States. Walnut Creek: Alta Mira, 2001.

Philander, P. J. Uurglas. Kaapstad: Nasionale Boekhandel, 1955.

-------. Vuurklip. Kaapstad: Nasionale Boekhandel, 1960.

. Zimbabwe. Kaapstad: Nasionale Boekhandel, 1968.

Konka. Johannesburg: Perskor, 1978.

Venster. Johannesburg, Kaapstad: Perskor, 1982.

Ostrakon. Kaapstad, Johannesburg: Perskor, 1986.

"Klein halfaampie, twee sort wyn. .. ." Die Volksblad, 16 Sept. 1989: 13.

Rebunie. Kaapstad: Human \& Rousseau, 2000.

en Langdown, A. A. Die bruin kokon. Stellenbosch: Kosmo-uitgewery, 1965.

Philander, Peter. "A Bridge for the Generations." Tydskrif vir letterkunde 43.2 (2006): 186-89.

Pwiti, Gildbert. ed. Caves, Monuments and Texts. Zimbabwe Archaeology Today. Uppsala: Uppsala U (Department of Archaeology and Ancient History), 1997.

Randall-MacIver, David. Mediaeval Rhodesia. 1906. London: Frank Cass, 1971.

Rautenbach, Fanus en Retief, Martie. '"n 'Banneling' kom kuier." Die Huisgenoot 25 Aug. 1972: 20-21.

Summers, Roger. Zimbabwe. A Rhodesian Mystery. 1963. Johannesburg: Thomas Nelson, 1965.

. Ancient Ruins and Vanished Civilizations of Southern Africa. Cape Town: T. V. Bulpin, 1971.

Van der Ross, R. E. Coloured Viewpoint: A Series of Articles in the Cape Times, 1958-1965 by R.E. van der Ross. Compl. J. L. Hattingh and H. C. Bredekamp. Bellville: U of Western Cape (IHR), 1984.

Vermaak, Jan B. "Die bruin kokon—P. J. Philander gesels. Prisma 4:A (1989): 2 